\title{
An insight into the history of Balkan Slavic languages Macedonian perspective
}

Keywords: accelerated evolution; contact changes; communicative hierarchy

Słow a klucze: przyspieszona ewolucja; zmiany kontaktowe; hierarchia komunikatywna

The thesis we would like to defend is founded on the following assumptions:

- most of the impulses stimulating the evolution of a language come from the semantic plane;

- a language has two types of means for conveying information; these are lexical and grammatical means;

- there is a natural hierarchy of the degree of importance of the information conveyed through an act of linguistic communication;

- there is a tendency to convey the most important parts of the information with the aid of maximally regular, predictable, transparent markers - in other words: with grammatical means; in still other words: the most important information is being grammaticalized;

- the most important information is the one allowing identifying the spoken-of events and of the participants of these events; they must be identified from the point of view of the speaker and from the point of view of the addressee; 
- to identify an event for his addressee, the speaker must a) evaluate its truth-value, b) define its internal temporal organization, c) locate it on the temporal axis with relation to the speech-event... ; to identify a participant of an event for his addressee, the speaker must a) inform him whether he himself identifies him, b) inform him whether the participant is human or not, c) if not human - whether it is a living being or not, then d) if living - to define its sex... etc. - as can be seen, we are speaking here about the information grammaticalized in the form of the so called grammatical categories present in the majority of the known languages, among others in the IndoEuropean languages ${ }^{1}$;

- in the course of time another omnipresent source of the linguistic change - the phonetic processes - can make some grammatical categorical markers not sufficiently clear and then the markers would be changed / reconstructed, strengthened, or new markers would be supplied;

- the pace of the linguistic evolution depends to a great extent on the topographic, economic and social conditions in the area in question: are the inhabitants of the area all speakers of the same languistic code?; if not - which is the prestigious hierarchy of the codes in use?, which is the linguistic policy of the ruling powers?, which is the interrelation of the linguistic, confessional and administrative borders?, etc.

- it is a well known fact that in a multilingual environment, without a clear linguistic policy controlled by the civil administration, the speed of evolution is greater, especially in what concerns less prestigious languages.

The above assumptions are a basis for our ideas 1 . about the universal parameters defining the direction and pace of linguistic evolution and 2 . about the historical path of development of South-Eastern Slavic as an antological/ classical example verifying that idea.

The Slavs appeared in the Balkans in the seventh century A.D. and reached Constantinople, Salonika, and also the South of the Peloponnesus, and survived to our days in its north-western part. Z. Gołąb in his study about the language of the first Slavs in Greece (Gołą 1989) writes: "The seventh century A.D., the period considered by historians to be the very beginning of

1 The presented hierarchy of the importance of particular semantic fields may appear arbitrary, but as of now we find no conterarguments undermining that hierarchy. 
the so-called "dark ages" in the history of Europe, is decisive for the formation of the etnographic map of the southeastern part of this continent, a map which has survived without essential changes to the present day. The great (or rather, fateful) historical event responsible for the entire subsequent ethnolinguistic history of the region (called popularly, since the Turkish conquest in the 15th century, "the Balkans") was its invasion by a new wave of "barbarians" from the North, the Slavs [...]" (op.cit., p. 5). The analysis of the Slavic toponyms in Greece and of the Slavic loan words in modern Greek dialects, which is the object of the quoted study whose purpose is to enrich our knowledge about the relative chronology of development of the Common Slavic / Proto-Slavic language, leads Gołąb to the conclusion that "[...] there is no doubt that the Slavs who penetrated into the Peloponnesus in the 7th and 8th centuries and settled there spoke a dialect that can be classified as still belonging to the Proto-Slavic II stage." (here follows a list of linguistic facts on which the above constatation is based) "[...] but alongside these archaic features there were in the oldest Slavic dialect in the Peloponnesus already some characteristics clearly indicating its belonging to the Macedo-Bulgarian group [...]" (op.cit., p. 44).

It is not easy to reconstruct in details the path of historical evolution of the Macedo-Bulgarian dialectal complex. There are still many questions. We know, however, the actual results. It is the review of these results carried out from the point of view of the semantic categories as signalized above that is our goal in this text.

In the course of time, at the territory occupied by the Macedo-Bulgarian dialect group appeared two strong innovative centers, which resulted in the formation of two diferent dialect complexes: Macedonian in the West and Bulgarian in the East. As far as contact and influence of the local prestigious languages are concerned, the western complex was primarily in contact and under the influence of Balkan Romance, while in the East Greek, and then Turkish, were more influential.

In comparison with other members of the so-called Balkan Linguistic League (BLL), the Slavic dialects in the period of their first appearance in the peninsula represented a northern, relatively conservative branch of the IndoEuropean language family and, consequently, they underwent deeper change in the subsequent process of "balkanization". 
The processes labelled as "Balkan" (in the sense that they were 'characteristic of the foundation and development of the BLL') are more numerous and more advanced in the West than in the East; their core is the western Macedonian dialect complex (cf. Vidoeski 1998).

Both Macedonian and Bulgarian were standardized relatively late. The processes of standardization of the two dialect complexes were considerably different.

First attempts to standardize Bulgarian appeared already around the half of the 19th century. The process still had continued after the formation of the independent Bulgarian state in 1878 , till the half of the 20th century. The main problem stimulating the discussion was the great difference between the "balkanized" vernacular and the archaic Church Slavonic, as well as between the Bulgarian vernacular and the Slavic grammatical standards functionning in the North Slavic languages, first of all in Russian, which is a model language for the first Bulgarian grammarians. Finally, the decision was made: it is the vernacular, the eastern dialect complex that will become the base of the literary standard, but many questions still remained open and the last serious interventions were made no earlier than around the half of the 20th century. On the other side, the Macedonian standardization was successfully carried out at once after the Second World War and the formation of the Yougoslav Federal Republic Macedonia. Here, the first attempts at standardization are also recorded to have appeared around the half of 19th century, but they all poinetd in the same direction: the central dialect of the western dialect complex, seen as the core of the Macedonian linguistic territory, was accepted as a base of the standard.

Before the first attempts at standardization at both territories we can observe diglossia: on the one side - the vernacular, the folk dialects, among them some prestigious town dialects, on the other - the local variants of Church Slavonic as the language of the educated elites, usually connected with the church. Historical sources registering folk materials are scarce: isolated words, isolated (morpho-)syntactic constructions included in some church or state documents. Therefore, our main source here are (a) dialect field materials included in numerous dialect monographs and/or published as such in dialect-text antologies, as well as (b) oral folk literature and then (c) the first books with Macedonian and/or Bulgarian folklore materials. Our 
present-day Macedonian field materials are richer than Bulgarian; unfortunately, Bulgarian linguistic atlases do not publish original field materials.

In this text, we present the results of the so-called balkanization processes still active or registered as active in the past in the South-Eastern Slavic verbal and nominal systems, founded mainly on Macedonian dialect or standard materials.

\section{Verbal System}

\section{Aspect - Restructuring the Inherited Aspectual Markers}

It is a universal need for language evolution to be in a constant search for ever more transparent grammatical markers for the purpose of precisely transmitting information. From the point of view of the theory of complex adaptive systems, the environment has a significant role in the creation of new nuclei which establish new relationships with the channels. The LatinRomance and the Balkan linguistic environment contributed to the decrease of the inventory of certain inherited markers, yet simultaneously contributed to the restructuring and introduction of more transparent grammatical markers. The category of 'aspect' in the Macedonian language is torn between the inherited models (morphophonological vowel and consonant alternations, a larger number of suffixes), and a non-Slavic understanding of aspect (predominantly through the imperfect-aorist opposition). The Macedonian language approaches the perception of aspect as an opposition: moment - duration, being transferred to the category of tense: aorist-imperfect. Between the opposition moment-duration, there is iterativity as a part of inherited durativity/ imperfectivity. In Macedonian, the older (morphophonological) aspectual markers are fading away and 3 main markers are being imposed ( $\boldsymbol{a}$ and $\boldsymbol{b}$ - perfectivity, $\boldsymbol{c}$ - imperfectivity):

a) Prefixes as the basic aspectual markers for perfectivity (which does not exclude their power as carriers of semantic information). In the $a$-group, the prefixes are the basic aspectual markers (шета-прошета...). A large group of newly-formed (foreign) verbs ending in -upa make an aspectual change with the prefix $u з(c)$-, which contains a meaningful component - completing the action as a whole, and in this manner it becomes a universal aspectual marker. 
b) The suffix -H-, as an inherited carrier of the basic perfective information (momentivity), enables the formation of a 'general' perfective base (седи-седне,... паѓа-падне,...), with the possibility of further prefixed semantic modifications. In particular, the -H- base is maximally open for further semantic modifications:

падне-испадне-допадне-пропадне-западне-припадне; лежи-легнезалегне-прилегне-одлегне-подлегне-разлегне-излегне..

c) The suffix -(y)в-a is becoming a universal aspectual marker for imperfectivity (including iterativity). It is imposed on perfective/perfectivized bases (трча-претрча-претрчува), and it always has the power to be imposed on the -H- base (semantically the most general - momentivity) and to create new double nuclei on the side of the inherited pairs/ series of aspect.

E.g.:

\begin{tabular}{|l|l|l|}
\hline $\begin{array}{l}\text { imperfective } \\
\text { леж- }\end{array}$ & perfective $>$ & imperfective \\
лежи & лег-н- & лег-н-ува \\
& легне & легнува \\
& од-лег-н-е & од-лег-н-ува \\
& из-лег-н-е & из-лег-н-ува \\
& за-лег-н-е & за-лег-н-ува \\
& по-лег-н-е & по-лег-н-ува \\
& при-лег-н-е & при-лег-н-ува
\end{tabular}

The perfective verbal base, which is layered with the aspectual markers, is most frequently the basic nucleus for aspectual modification. Hence, this is the end of the inherited pre-Slavic aspectual division, instigated by the 'types of actions'.

Serbian: доводити довести доносити донети превозити превести Macedonian: доведува доведе донесува донесе превезува превезе 


-volish
\begin{tabular}{|l|l|l|l|l|}
\multicolumn{2}{c}{-ved- } & -vod- \\
\hline prowadzić się, & dowieść & dowodzić & доведе & довед-ува \\
\hline doprowadzać/doprowadzić & wywieść & wywodzić & воведе & вовед-ува \\
\hline naprowadzać/naprowadzić & wywieść się & wywodzić się & заведе & завед-ува \\
\hline oprowadzać/oprowadzić & odwieść & odwodzić & изведе & извед-ува \\
\hline przeprowadzać/przeprowadzić & przywieść & przywodzić & наведе & навед-ува \\
\hline przyprowadzać/przyprowadzić & zwieść & zwodzić & одведе & одвед-ува \\
\hline wprowadzać/wprowadzić & zawieść & zawodzić & подведе & подвед-ува \\
\hline wyprowadzać/wyprowadzić & uwieść & uwodzić & преведе & превед-ува \\
\hline zaprowadzać/zaprowadzić & & & приведе & привед-ува \\
\hline
\end{tabular}

The main hotbed of this occurrence is in the Southwestern peripheral Macedonian dialects, which held the strongest ties with the non-Slavic Balkan languages. It is precisely those, and especially the Latin-Romance element, that were the "transmitters" of the processes of bringing the understanding of verbal aspect closer to the SAE languages.

Excerpt from B. Vidoeski (1999: 229):

[...] Layers have been added to the base of the perfective verb, and the aspectual function has been taken over by the suffixes $(-v-,-u v-),[\ldots]$.

So, for example, in the Southwestern dialects, in the direction of Struga Ohrid - Prespa - Lerin, and to the south to Korcha and Nestram - Kostur, all the old models came down to one main word-formational model with the suffix $\underline{-\boldsymbol{\sigma}-}$, which is added to the thematic part of the perfective verb. Compare: $k y n-$ в-и, плат-в-и (: плати), измен-в-и, тур-в-и, мен-в-и, поклон-в-и, товар-в-и, от(в)ор-в-и, род-в-и, зајд-в-и, дојд-в-и, вид-в-и, пад-в-и, влег-в-и, прост$b$ - $u$, etc. In those cases where phonetic barriers appeared, the base then expanded and new transformations emerged, for example: лег-ин-в-и (: легин- $a+$ легни), падин-в-и (: падина); with the verbs whose root morpheme ends in -в-, the suffix expanded to -ив- : заборав-ив-а (: заборав-и), поправ-ив-а, оживив-а (: ожив-и), оздрав-ив-а (: оздрав-и), отков-ив-а (: откови), обув-ив-а (: обув-u), and afterwards that model could cover other verbs as well, where the need to avoid impossible consonant sequences appeared, as in закаил-ив- $a$ (-илв-), изведр-ив- $а$ (: изведр-и), or with the verbs of -н-, of the type легн-ив- $а$ (: легн-и) along легин-в- $a$. With the other verbs the aspectual function is mor- 
phologically expressed with the thematic vowel. Compare фарл-е (: фар л-u), карст-е (: карст-и), пушч-е (: пушч-и) along пуши-в-и (Boboshtica).

After the integration of the old models into the Korcha and Kostur dialects was completed, two new word-formational types of imperfective verbs were created: a) with the suffix -в- : куn-в-и (: куn-и), покри-в- $а$ (: покрие), разле-в- $а$ (: разле-е), запја-в-а (: запее), чу-в- $а$ (: чу-е), b) with the suffix -ив- : заборавив-а (: заборав-u); while regarding the old models, only the following was left: зовир- $а$ (: зовр-и), умир- $a(:$ умр-и). The verbs of the type запина (: запн-и) are found in a process of transformation, so that in the Korcha dialect there are parallel forms: запина, касина (: касни), скор'ина (: скорни), верина (: варни) and: легин-в- $a$, падинва, whilst in the Nestram dialect запн-ив- $а$, легн-ив- $а$, сопн-ив-а."

\subsection{Aspect-Tense}

One of the initial problems that has been affecting the development of the Macedonian verbal system is the relationship of perfectivity-imperfectivity (aspect) vs. the relationship of aorist-imperfect (tense).

aspect

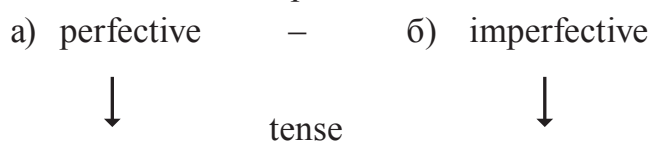

a) aorist $\quad-\quad$ б) imperfect

As it is well known, when forming the aorist of verbs, the three verbal groups (a, $\boldsymbol{e}, \boldsymbol{u})$ are divided into five subgroups: $\boldsymbol{a} \boldsymbol{o} \boldsymbol{u} \boldsymbol{e} \boldsymbol{\varnothing}$. (Koneski 1981)

Here we would like to demonstrate that the restructuring of the aspectual relations is based ever more and more on prefixes as basic aspectual markers, although that modification frequently refers to a part of the action, not its wholeness. Yet even with such an "incomplete coverage", prefixes are becoming basic aspectual markers (for perfectivity), while suffixes (-yвa, with the recent addition of $-\boldsymbol{u p a}$ ) are specialized as aspectual markers for imperfectivity. The need for a more univocal aspectual differentiation of verbs can be seen through the ever more and more frequent use of the prefix $\boldsymbol{u} 3-/ \boldsymbol{u c}$ - with verbs ending in -upa, hence these prefixes are only aspectual markers (демантира-издемантира, контактира-исконтактира). 
Koneski notes the propensity for the increased productivity of the morphological means (prefixes), with the help of which perfective verbs are formed (Koneski 1981: 169), and he specifically emphasizes that the reinforcement of the productivity of the prefixes is highly expressed in the areas where contacts with the other Balkan languages are the strongest.

This brings us to another, more significant shift in the abovementioned relation, i.e. a shift in aspect with regard to the definite past tenses. Namely, the propensity for blocking the formation of the aorist of imperfective verbs is almost completely realized in modern Macedonian.

With such a tendency, the understanding of the opposition perfectivityimperfectivity is simplified to a certain point, as opposed to the opposition aorist-imperfect, as they are also nearing the "Balkan", non-Slavic perception of the suitable oppositions, where the opposition perfectivity-imperfectivity is expressed mostly through the aorist-imperfect relation.

Moreover, a whole group / class of verbs whose aspectual difference has been noticed only through the subgroups, have moved towards prefixation, which uniformly determines the perfect aspect. For some of these verbs, the change of the subgroup brings about a vowel or/and consonant alternation. But, on its own, it does not carry enough information about aspect.

Examples:

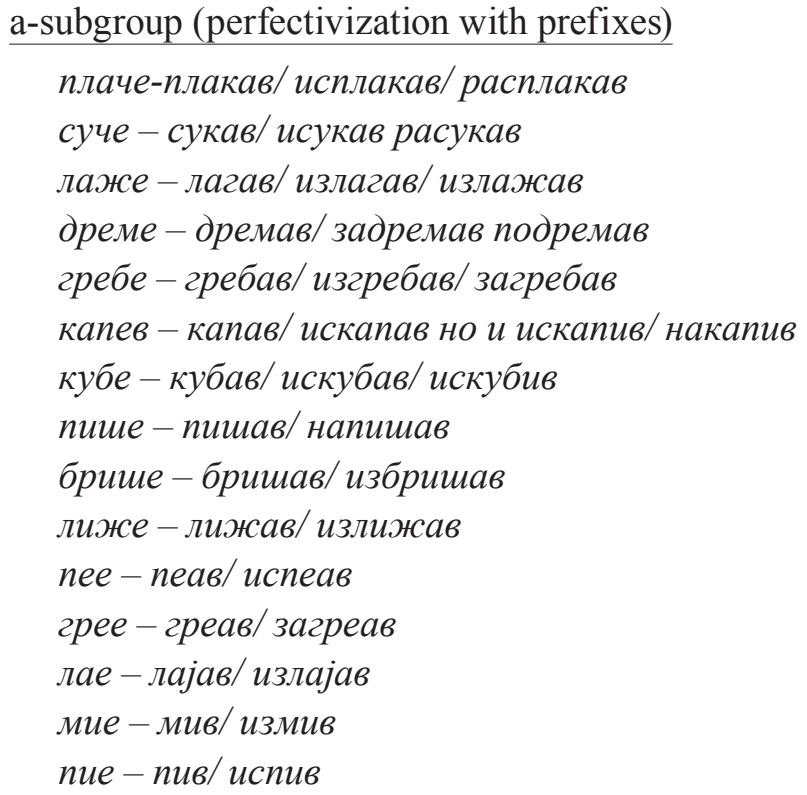




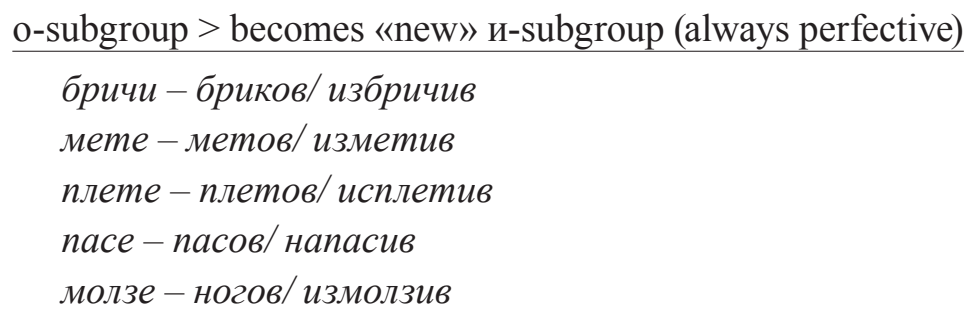

On the other hand, the a-subgroup is not sufficient on its own to determine aspect / tense, because on almost every occasion aspectual markers are layered. They are often prefixes for the a-group, and, as it can be clearly seen above, this is happening with a certain number of verbs from the e-group. The rest of the verbs from the e-group that glide into the a-subgroup employ the sufix $-H(e)$ as a marker for perfectivity. For example:

\begin{tabular}{|c|c|c|c|}
\hline \multicolumn{3}{|c|}{ e-group } & a-subgroup \\
\hline препне & - & препнува & препна \\
\hline шепне & - & шепнува & шепна \\
\hline урне & - & урнува & урна \\
\hline сметне & - & сметнува & сметна \\
\hline седне & - & седнува & седна \\
\hline стане & - & станува & стана \\
\hline падне & - & паѓ (паднува) & падна \\
\hline скокне & - & скокнува & скокна \\
\hline \multicolumn{4}{|c|}{ Table of subgroups (perfective verbs): } \\
\hline \multicolumn{3}{|c|}{ aorist } & imperfect - bound form \\
\hline \multicolumn{3}{|c|}{ e-group / a-subgroup } & $\begin{array}{c}(\dot{\kappa} e, \text { aкo, } \partial a+\text { imperfect of perfective } \\
\text { verb) }\end{array}$ \\
\hline \multicolumn{4}{|c|}{$-H(e)$ as aspectual marker } \\
\hline \multicolumn{3}{|c|}{ паднав } & паднев \\
\hline \multicolumn{3}{|c|}{ викнав } & викнев \\
\hline \multicolumn{3}{|c|}{ секнав } & секнев \\
\hline \multicolumn{3}{|c|}{ седнав } & седнев \\
\hline
\end{tabular}


Table of subgroups (perfective verbs) (cd.)

\begin{tabular}{|c|c|}
\hline aorist & imperfect - bound form \\
\hline e-group / a-subgroup & $\begin{array}{c}\text { (ќe, ако, } \partial a+\text { imperfect of perfective } \\
\text { verb) }\end{array}$ \\
\hline признав & признаев \\
\hline кренав & кренев \\
\hline скинав & скинев \\
\hline станав & станев \\
\hline настинав & настинев \\
\hline \multicolumn{2}{|c|}{$\begin{array}{l}\text { prefixes as aspectual markers } \\
(3 a-n p e-, \text { на- , по-, из(c)-... }\end{array}$} \\
\hline -колнав & -колнев \\
\hline -пииав & -пимев \\
\hline$-б р и ш а в ~$ & -бришев \\
\hline -лажав & -лажев \\
\hline -стругав & -стругев \\
\hline -лажсав & -лажев \\
\hline -плакав & -плачев \\
\hline -сукав & -сучев \\
\hline -капав & -капев \\
\hline -сипав & -cunes \\
\hline$-\kappa у б а в$ & $-к у б е в$ \\
\hline -гребав & -гребев \\
\hline -дремав & -дремев \\
\hline$-в р з а в$ & -врзев \\
\hline- пеав & - -пев \\
\hline (се) -смеав & (се) -смеев \\
\hline -греав & -греев \\
\hline -живеав & -живеев \\
\hline -трајав & -траев \\
\hline$-ч м$ мајав & - -маев \\
\hline -лајав & $-л а е в$ \\
\hline
\end{tabular}


Therefore it can be said that blocking the formation of the aorist of imperfective verbs has also carried about a redefinition of the subgroups. i.e. a rise in the transparency of the aspectual markers, with the aim of coordinating the relation between the tense and aspect, and heading nearer to the "Balkan", and by that, the "European" understanding of the aspect-tense opposition.

Hence, the vowel - $\boldsymbol{a}$ - in the a-group and the a-subgroup can now be said to be insufficient for determining the aspect, which is the reason for us considering it aspectually unmarked (not only in the a-group, but also with regard to the $a$-subgroup). So in the $a$-subgroup in aorist, regarding the a-group, and partially in the $e$-group, aspect is modified by the prefix, while with the other (a large part of) verbs of the $e$-group, in the a-subgroup the information about the aspect (perfect) is carried by the sufix $\boldsymbol{- \mu}(\boldsymbol{e})$.

Concerning the $i$-subgroup, which (according to Koneski 1981) appears only in the $i$-group, there are possible movements even from the other verb groups with the verbs of the following types: измети, измолзи, избричи, because (regarding the pre-Slavic inherited mechanisms) $\boldsymbol{- u}$ - carries with it aspectual information on perfectivity. For example: фаќa - фати; враќa врати; раѓa - роди; плаќа - плати; фрла - фрли; пушта - пушти.

As well as:

imperfective verbs

a - group

nушта

товара

спрема

прима

снима

отвора

затвора

остава

поправа perfective verbs. (+aorist)

и-group / и-subgroup

пушти

товари

спреми

прими

сними

отвори

затвори

остави

поправи

Additionally, quite a significant part of the verbs in the i-group belong to the $i$-subgroup, yet there too, in a large number of cases, prefixation is 
necessary for further aspectual determination in perfectivity (носи, оди, прави, меси, / -носив, -одив, -правив -месив.). This amounts to the fact that the vowel $\boldsymbol{-} \boldsymbol{u}$ - still carries information about the aspect and is not as indifferent towards aspect as the vowel - $\boldsymbol{a}$ - in the $\boldsymbol{a}$-subgroup.

The basic impulse for this attempt to sketch the exhibitors of aspect and tense (after their restructuring) lies in the e-subgroup.

With the verbs of the $i$-group, this subgroup appears in the following cases (in 1st person singular, the forms of aorist and imperfect are homonymous):

Subgroups:

$\boldsymbol{u}$-group / e-subgroup

\begin{tabular}{|c|c|c|}
\hline aorist & "new" aorist & imperfect (bound forms) \\
\hline оздравев & го оздравив, заздравив & оздравев \\
\hline оглувев & го оглувив & оглувев \\
\hline разболев (се) & го разболив, преболив & разболев \\
\hline оголев & го оголив, соголив & оголев \\
\hline ослепев & го ослепив, заслепив- ев & ослепев \\
\hline ослабев & го ослабив, заслабив, & ослабев \\
\hline осиромашев & го осиромашив & осиромашев \\
\hline почрвенев & го почрвенав, зачрвенив & почрвенев \\
\hline почрнев & $\begin{array}{l}\text { го почрнав, почрнив, } \\
\text { исирнив }\end{array}$ & почрнев \\
\hline потемнев & $\begin{array}{l}\text { го потемнав, затемнав, } \\
\text { затемнив, истемнив, } \\
\text { потемнив }\end{array}$ & потемнев \\
\hline обелев & $\begin{array}{l}\text { го обелив (образот), } \\
\text { избелив, забелив }\end{array}$ & обелев \\
\hline окривев & $\begin{array}{l}\text { го окривив, искривив, } \\
\text { закривив }\end{array}$ & окривев \\
\hline изгорев & $\begin{array}{l}\text { го изгорив, загорив, } \\
\text { прегорив, догорив }\end{array}$ & изгорев \\
\hline прекапев & го прекапив, искапив & прекапев \\
\hline загрмев & загрмив со, прегрмив & загрмев \\
\hline
\end{tabular}


From the table above it can be seen that there is a small number of verbs that are placed in the e-subgroup, yet they too have limitations (intransitivity). On the other hand though, the propensity for a more frequent and strengthened prefixation (with the aim of aspectual modification) enables more combinations and the formation of verbs from the i-group, which can be placed only in the $i$-subgroup.

What can therefore be stated is that just as in the other processes of grammaticalization and movement of different (more transparent) markers, so has the unproductivity of the e-subgroup led to its unrecognizability as any type of exhibitor of aorist/ or perfective aspect.

Although there is a significant number of examples of the dual use of these verbs, on the one hand, the $i$-subgroup, as the basic marker of univocal representation of the "syncretism" of perfectivity-aorist, is slowly winning the battle. On the other hand, the vowel $\boldsymbol{e} \boldsymbol{e}$ - as a marker for the imperfect of the imperfective verbs, has slowly been taking its place as a universal imperfective marker as well, which is an even more univocal representation of the "syncretism" of imperfectivity-imperfect. This allows for an easier and more univocal formation of the imperfect from the perfective verbs as well. Since there exist more univocal and transparent markers of aspect (such as: prefixes, infixes, suffixes), the vowel $-\boldsymbol{e}$ - loses its perfect aspect (or the $e$-subgroup in aorist) and becomes only a marker of imperfect (regardless of the aspect). Furthermore, this enables a whole "new" class of perfective verbs, through the aorist base, to form imperfect specifically with the sole marker of $-e$, with the aim of allowing all the verbs (regardless of the aspect) to enter into both tense and modal constructions, as well as separating and univocally differentiating the constructions with tense definiteness from those with modal meaning. This provided for the unimpeded expansion of the irrealis conditional of Balkan type (ќ + имперфект), which has become dominant in the Macedonian language as well. Moreover, the conditional, especially the irrealis, completely integrated in temporal system, in which the vowel $e$ becomes the basic marker for both the perfective and imperfective verbs. As such, it has required the need for restructuring the subgroups with the single aim of a more univocal differentiation of the imperfect and aorist. This is how the homonymous forms of the following type are lost: 
Examples:

Вчера загрмев со гласот. (aorist - "old" e-subgroup)

Да не бев болен, вчера ќе загрмев со гласот. (imperfect - bound form)

Вчера загрмив со гласот ("new” aorist)

Јас поцрнев на море.

(aorist - "old" e-subgroup)

Ако не користев крем, ке поцрнев многу. (imperfect - bound form)

Дризла ја поцрни Маркова река. (“new” aorist)

Брилијантниот Бејл го затемни Интер. ("new" aorist)

Да ја затемнев собата, немаше да те видам. (imperfect - bound form)

From the above-described, it can be concluded that:

The increased productivity of prefixation regarding aspect has eased the restructuring of the imperfective verbs in imperfect, and the perfective verbs in aorist. When the aspectual differentiation became transparent and univocal enough, that is when the restructuring of the subgroups began, i.e. the secondary markers of aorist, the aorist has kept its 3 subgroups ( $\boldsymbol{a} \boldsymbol{u} \boldsymbol{o})$, while the subgroup - $\boldsymbol{e}$ - was "yielded" to the imperfect so as to be able to univocally recognize the forms of the imperfect of perfective verbs, and to connect to the vowel $\boldsymbol{e}$.

In such a manner the Macedonian language equals the opposition of perfectivity-imperfectivity with the opposition of aorist-imperfective, thus creating two differentiated systems with regard to the opposition of tense-modality. Being considered from a point of view wider than the processes motivated in the framework of the Balkan Linguistic Community, these processes (typologically) can be connected with the processes and the aspect-tense-modal oppositions in the other European languages (e.g., French, Italian, German, English).

\section{Tense - Modality}

Regarding the verbal system (aspect, compound tenses), modern Macedonian shows more similarities with the Western dialectal compound, especially with the Western peripheral dialects. In the verbal system, besides the tendency to approximate the category of aspect towards the "Balkan" 
understanding of that category, there is a tendency, on the one hand, to transfer constructions of the type $c y_{M}+л$-participle into the field of epistemic modality, and. on the other hand, to use the constructions of the type uмам $+\mu / m$-participle more frequently. In modern Macedonian, the constructions with "сум" and $л$-participle, regarding their functional load, are much closer to the field of epistemic modality: admirative, dubitative, distance (Friedman 2011). In his works, Friedman also talks about other features (such as: resultativity, evidentiality, non-confirmativity) regarding both constructions with $\pi$-participle and constructions with $\mathrm{H} / \mathrm{m}$-participle. The subjective (personal) opinion is embedded in those constructions $\left(c y_{\mu}+\pi\right.$-participle $)$ and this feature begins to be used broadly in modern Macedonian, especially in some functional styles (e.g. journalistic style), while constructions with uмам $+\mu / m$-participle are used for expressing more neutral past tense where there is no personal opinion and the event is presented as a fact.

From the present viewpoint, it can be stated that the use of the имa constructions is becoming more and more frequent, and has already become the main construction for expressing the (indefinite) past and resultativity. What is significant is that it concerns a past action (regardless of whether it is relevant at the moment of speaking, whether it is marked for tense, or whether it is directly witnessed). All those characteristics are secondary, while the primary point is that it focuses on a past fact (strong conviction), or a neutral (non-subjective) relationship. For example (a conversation in the Ohrid dialect): Оломлани Љупчо имат дојдено од Америка. Имат донесено ногу пари. Имат купено куќа, кола. Имат изградено хотел, имат вработено поќ лууге. А порано имат живеено во куќана од Алија под кирија. Имат седено и кај Мамута. Имат продавано весници по улица. Јас му давав бакшиш. Не знам дал уште е Охрид, ил си имат ојдено Америка. So, there are: indefinite past; located on a temporal axes (last year, before, yesterday); perfectivity - imperfectivity of the action; resultativity; witness evidentiality and non-witness evidentiality; but the most important point is transmitting the action as a fact, without taking a subjective view.

The situation in the Ohrid-Stuga dialect shows this tendency. In this context, aside from: Тој имат ојдено на плажа; Тој имат купено куќа Чариија; Тој се имат качвено на планина; one can notice constructions of the type: Тој немат можено да дојт; Тој имат морано да се качит на кров; Тој имат мислено дал' да купит кола, etc. Concerning 
the constructions with $c y m+H / m$-participle, the situation in such dialects is yet more advanced. So, aside from the constructions of the type: јаден сум, пијан сум, седнат сум, вратен сум, дојден, сум, јавен сум, Биден сум на плажа; the following construction is also possible: Toj е биден фризер.

This is a tendency that is spreading into the modern language, which makes constructions of the following type more frequent:

\section{Examples:}

1. На ревиите има носено модели на познати креатори како што ce...

2. Регионот го има носено името Македонија низ векови,

3. Тој има работено на проекти во Центарот за проучување на меѓународните односи од Париз.

4. Имаш трчано на маратон?

5. Инаку јас имам одено во таа градинка, ама тоа било многу одамна,

6. Тарчуловска: Љубе ниту има дојдено, ниту ми се има јавено

7. Тој често оди во главната железничка станица на Диселдорф и таму има спиено во шкафовите за багаж,

8. Имам шетано низ планини, собирано печурки, но се случи во град на асфалт да ме касне змија.

9. Многу пати имам мислено на ова и никако да го смислам.

10. Толку многу имам зборувано и мислено за круговите...

11. Колку само се имам смеено на тие песни...

12. На Клетниции од Виктор Иго имам плачено...прекрасна книга.

13. Единствено Пјер де Кубертен - таткото на модерните олимписки игри подолго време има седено на престолот на МОК

14. Груевски има седено на клупата на Вардар, потоа беше тренер и на Пелистер, Силекс, Саса, Тиквеш...

15. Колку пати имаме заедно седено на чардакот од неговата куќа.

16. Тоа ги навело на помислат дека некој има влегувано внатре и предложсил на мајка му да ја известат полицијата.

17. Се имам качувано по карпи, ама не беа нешто многу страшни

18. Мислам дека порано имам отварано ваква тема..

19. Има скокано и на аеродромите во Стенковеи, Куманово... 
20. Тој има скокнато од двете највисоки згради во светот, како и од статуата на Исус во Рио де Жанеиро.

Furthermore, the $\pi$-perfect is moving more and more away from the tense scale to the modal scale, i.e. it is being used in its modal meanings because of /+/-factivity/. Regarding this, the journalistic style gains a strengthened dimension of 'distance' for the said statements. This does not have to regard the non-witness (renarrated) action, it does not even have to regard indefiniteness in the past, but it primarily focuses on the meaning that the transmitter of the information does not want to take any responsibility for what has been said or bear the consequences that can follow from such an action.

The following examples illustrate this use of the $\pi$-construction:

1. Градоначалникот Коче Трајановски вели дека на патеката светилки ќе има дури в година, но немало да биде мрак оти светло имало на другата страна на Вардар.

(So the Mayor says: [...], но нема да биде мрак оти светло има на другата страна на Вардар; the journalist does not believe that the lights from the other side are enough, and he/she does not think that there will not be darkness, so he/she does not wish to transmit that information and to assume responsibility for what has been said, thus using the л-construction) = not taking responsibility for the reported/ transmitted information;

2. Во осум ленти се влегуваше во Македонија од Гриија. Најбројни беа српските државјани, денеска им завршувал десетдневниот одмор.

3. Основното училиште во Влае, тврдат во Владата, ќе се градело од следната година, а забавувањето на работите биле затоа ито општината била инертна.

4. Градоначалникот на Карпош не беше поканет на денешната иеремонија во неговата општина, иако тој вели дека за проектите на Владата општинската документација се подготвувала без проблем.

5. Лекарите побараа средба и со премиерот Груевски, тој вели ќ ги примел но, за него трансформачијата е издржана бидејки е донесена по претходна стручна анализа. 
6. Комесарот за економски и монетарни прашања Оли Рен, рече дека тимовите работеле деноноќно и дека преговорите ќе бидат завршени во следните...

7. Од МВР велат работеле на расчистување на случајот.

8. Но Владата вели работеле со полна пареа.

9. Грчката министерка за надворешни работи Дора Бакојани првпат јавно рече дека грчката Влада донела одлука за блокирање на влезот на земјава.

10. Мета од своја страна побара целосно и ефикасно спроведувағе на Охридскиот договор, кој, како што рече, имал битно значење за стабилноста на

11. Го прамав дали има пари, рече имал!

12. Оваа одлука за исплата на околу 2,5 милиони евра, владата ја донела на вчерашната седница - по два месеции доцнење.

These examples ilustrate that the movement of the $\pi$-constructions in the zone of modality has been profoundly put to use in the modern (colloquial and standard) Macedonian language. Aside from the competition of the constructions with $u_{м a} /{ } y_{M}+H / m$-participle, which are expanding their area of usage, becoming general complex preterite (preterite perfect, present perfect, compound perfect,...), several other factors that influenced the movement of this inherited Slavic construction (Slavic perfect) can be mentioned:

1. The $\pi$-constructions are unmarked for factivity (+- factivity), i.e. they are dependent upon the context: (non-witness evidentiality, renarration, distance, wonder, disbelief,...), in fact, such information is more commonly determined by context (somebody-one-said-that..., I didn't know that..., I can't believe that...).

2. The $\pi$-transmitter carries the information on indefiniteness on the temporal scale, and can also refer to a past, present, or future moment:

Дедо ми порано ми кажувал... $\quad$ Ти си носел дрва со години... Тој паднал од дрво... (past)

Гледам, си паднал. Тој знаел да трча. Ти си играл шах. Добро си дошол. (present-/ resultative/ admirative)

Паднал, та не станал... Бог ве казнил... (future) 
3. The $\pi$-form, in its broadest use (3rd person singular), does not carry any additional information on the most suitable aorist form (купил VS купи)

Тој купил кола - Тој купи кола

4. In such a case, the $\pi$-form is reduced merely to a general participle form, unmarked for factivity and tense, while the copula verb carries the information about person (in 1st and 2nd person singular and plural).

This tendency for an increased use of the uma-constructions (under the Balkan influence) and for the modal use of the $\pi$-constructions is completed in the far Southwest Macedonian dialects (Korcha dialect), is in full swing in an area of the Western peripheral dialects (Ohrid-Struga), and is taking over the modern Macedonian language, especially with regard to its stylistic marked use. The expansion of constructions signalling reserve for the truth value of the message shows the importance of a clearer distinction of the semantic category /+factivity/-factivity/.

In addition, with the ever increasing use of the constructions имам/сум $+H / m$-participle in modern Macedonian, and their movement towards the area of what is considered "general (complex) preterit", this largely corresponds to the processes in the other European languages. Namely, the modal categories: future, subjunctive, presumptive, conditional, etc., are commonly formed with the particles + appropriate verb form (personal verb form, infinitive, participle), while the compound past tenses are commonly formed with the auxiliary verb esse, habere, stare, + participle. Thus, from the typological aspect, the 'Macedonian' constructions: сум јаден, сум дојден, имам работено, имам носено, имам седено, еtс., are noticeable in the context of not only the Balkan linguistic environment (Albanian: kam punuar; Aromanian: am mă'kată,...), but also in a wider 'European' context for the constructions of the type: 


\begin{tabular}{|c|c|c|c|}
\hline $\begin{array}{c}\text { English } \\
\text { (Present perfect) }\end{array}$ & $\begin{array}{c}\text { German } \\
\text { (Perfekt) }\end{array}$ & $\begin{array}{c}\text { Spanish } \\
\text { (Present perfect) }\end{array}$ & $\begin{array}{c}\text { French } \\
\text { (Passé composé) }\end{array}$ \\
\hline I have eaten & $\begin{array}{l}\text { Ich habe gegessen } \\
\text { Du bist gekommen }\end{array}$ & He estudiado & $\begin{array}{l}\text { J'ai mangé } \\
\text { Il est tombé dans } \\
\text { le lac } \\
\text { (aller, venire, } \\
\text { arriver, partir, } \\
\text { entrer ....) }\end{array}$ \\
\hline
\end{tabular}

Viewed from the present perspective, the Macedonian language is an unbelievably interesting, complex, adaptive system, or a phenomenon in a wider framework. Its 'arms' include the inherited Slavic characteristics and the acquired Balkan characteristics. In its present 'independent' development, Macedonian uses all these means in order to articulate the conceptualization of the modern world in as univocal a way as possible, and to enhance clearer communication between the speakers.

$$
* * *
$$

\section{Nominal System}

We are presenting here an outline of the present-day Balkan Slavic nominal system as compared with the Church Slavonic system registered at the starting point of the Balkan history of the Slavs.

Let us start with the definitions of some basic notions characteristic of the theoretical frame of our description. We accept that the basic unit of the semantic structure of the text is a proposition, i.e. a predicate with its implied (=coded in its semantic structure) arguments.

There are two types of arguments: a) those referring to the material parts of the world and b) those referring to events; we shall address them respectively as a) material object arguments and b) propositional arguments.

Consequently, we distinguish three types of predicates: a) those informing about the relations between the material parts of the world - they accept material object arguments only, b) those informing about the intellectual, emotional, volitional attitude of the speaker toward the world around him they accept both material object arguments and propositional arguments, and 
finally c) those informing about our way of thinking about the events - they accept only propositional arguments.

Both predicates and arguments can be complex structures including more than one condensed proposition, forming a hierarchical construction.

We accept that a vocabulary of a natural human language includes three types of semantic units: predicates, shifters (as defined by R. Jakobson) and proper names.

As signaled in the foreword, our aim is:

- to present the evolution of the formal grammatical markers conveying information from the semantic fields active in the process of identifying the participants of the spoken of events,

- to check whether the grammatical evolution changed (restricted, enlarged) the quantum of information grammaticalized at the starting point of that evolution,

- to define the general direction of the evolutional processes evaluated from the semantic point of view.

\section{Man and Space}

At the top of the semantic hierarchy, among the material object arguments, there are those referring to men/humans and there are many special markers identifying human referents.

The old, inherited Indo-European grammatical means informing about the (semantic) roles of the material objects participating in an event were organized in the category of case and were signalized with affixes/endings glued to the respective nominal stems. Case is understood here not as a morphological form, but as a (semantically motivated) syntactic relation between the predicate expression and the implied argument expression. Case is a category of the Noun Phrase taken as a whole as reflected in the shape of its constitutive member.

The old cases were not numerous. They informed primarily - or so it seems - about the (active and/or passive) roles of the human participants of the event and about their location/movements in the physical space (cf. Fillmore 1966, 1968, Topolińska 1996, 2010, 2014).

A typical event as reflected in a typical proposition includes one or two human participants and one or two /- human/ material objects. 
Using the well known Latin case names we can characterize the ProtoSlavic cases as follows:

- Nominative (was and) is the case of the first human participant: doer, performer, agens; this role was signalized (a) by the corresponding ending and (b) by the categorical congruence of gender and number between the predicative and the argumental expressions, as well as (c) by the congruence of verbal personal endings (cf. the section on the referential system below) with the nominative argumental expression;

- Dative is the case of the second human participant: addressee, recipient, beneficient, experiencer; dative represents also the unique human participant if the nominative position is blocked; this role was signalized by the corresponding ending only ${ }^{2}$;

- Accusative is the case of the first material object whose reference in respect of the opposition / +/- human/ is irrelevant - it is the object affected by the activity of the first human participant, as signalized by the corresponding affix;

- Instrumental is the case of the second accompanying material object, an accessory to the performance of the action, as signalized by the corresponding ending.

- Locative is understood here as representant of all the net of spatial "cases", i.e. expressions defining the spatial parameters of the event. The relational spatial meaning of these expressions in Proto-Slavic was already signalized / controlled by prepositions - the preposed affixes; the old case endings became in this context irrelevant, purely conventional.

All the cases as presented above were adverbal, i.e. controlled by the verbal predicate. The unique adnominal case in the Proto-Slavic inventory was the genitive, which constituted a condensed proposition with the predicative meaning, usually the possessive relation sensu largo, conveyed by the case ending; if used in the adverbal position, the genitive functioned as a (partitive, negated...) variant of the accusative ${ }^{3}$.

2 There is one more form favorizing / human/ referents - the vocative; but it is not a case in the sense as discussed above; it is an argument of a virtual predicate of appeal functionning as an independent proposition.

3 All that is said above concerns NPs constituted by substantives and/or substantivized adjectives; NPs constituted by pronouns will be discussed in the following section of this text. 
Let us see now whether and how the Balkanization processes reorganized the category of case.

First of all, let us state that all the relevant semantic distinctions are preserved. All the changes concern the formal markers - exponents of these distinctions:

- the majority of the postpositive case affixes (endings) were blotted in the result of phonetic and/or phonological evolution;

- most often they were replaced by prepositive "adposition", i.e. prepositions; an organized net of prepositions is responsible, in the first place, for signaling spatial relations; then - through semantic derivation - one of them, the adlative *na is promoted to signalize also other dative and genitive relations (cf. Topolińska 2011); mutatis mutandis ${ }_{S b}$ is promoted to the instrumental function signaling the material "accompanying factor" argument as also referents of the so called commitative instrumental; finally, *od can appear as a marker of the "genitive" partitive function;

- the position of the nominative stays unchanged - it is still signalized by the number and gender congruence with the predicative expression as secured by the personal endings of the verbs;

- the central / +/- human / case, the accusative, in many dialectal systems achieves the role of casus generalis, a unique oblique case, when referring to "masculine human objects", but in other systems it is marked by the rigid linear order only (postposition in relation to the predicative expression) or even - in some southwestern Macedonian dialects - when referring to "masculine human objects", it is marked by the mentioned above "grammatical" preposition $n a$.

All the above solutions are valid for the NPs notwithstanding how complex their internal structure is.

\section{Person - the shifter-category}

Under the above title we shall speak about the pronominal subsystem of the SES nominal system. As we shall see, it has its own rules, and is not only more conservative and more stabile than the central substantival subsystem, but is also the source of the most important innovation in the actual nominal system of the SES: the grammaticalized category of definiteness. 
The three "grammatical persons" represent the link between the pragmatic and the semantic information conveyed through an act of linguistic communication. They represent respectively the speaker, the addressee and the "third persons" not included directly into the speech-event. As such they, or - more precisely - the markers relating to them, can be and are used to build a coherent net of signals enabling the identification of the participants not only of the speech events, but also of the spoken of events.

The pronominal subsystem of the SES preserves specialized morphological forms relating to the three central cases: nominative, dative and accusative; it has even double, stressed and clitical forms for these cases. Several Indo-European languages, among them Proto-Slavic, developed an additional, marked, emphatic pronominal paradigm, cf. e.g. present-day Macedonian constructions, as MI dade 'he gave me' as opoposed to MI dade $M E N E$ ' 'it's to me that he gave', or GO vidov 'I saw him' as opposed to $N E G O G O$ vidov 'it's him that I saw', etc.; cf. also French il m'a donnè á moi, je l'ai vu lui, etc. What is more, as mentioned above, not only accusative and dative, but also nominative has an emphatic variant, cf. Mac. gledaM more 'I see the sea' as opposed to JAS gledaM more 'it's me who sees the sea', čitaš kniga 'you read a book' as opposed to TI čitaš kniga 'it's you who read a book', etc. - the pronominal subject appears as a replica of the personal verb ending / verb form. In so far as the third persons are concerned, the nominative subject NP regularly appears and its replica is the verbal ending, be it the -0 ending, as in the singular present or aorist paradigm. Finally, there is also a possessive (i.e. $\mathrm{G}=\mathrm{D}$ ) emphatic variant, cf. majka $M I$ as opposed to majka MI MOJA, etc.

Mutatis mutandis the same pattern was used for case marking in the new (see below) /+ definite/ case paradigm, obligatory in some Western Macedonian dialects, facultative in other Macedonian and some Bulgarian dialects; it was introduced as obligatory into the Macedonian standard. As the result (and - cf. below - with the introduction of the article), today we have two case paradigms in the Macedonian standard, (1) one /- definite/, i.e. not identifying the referent of the NP, and (2) the other /+ definite/, i.e. identifying that referent, $\mathrm{cf}$. 
(1) N čovek

D na čovek

A čovek

I so čovek

L na, vo, do, od...čovek

$\mathrm{G}=\mathrm{D}$
(2) $\mathrm{N}$ čovekOT

D MU na čovekOT

A GO čovekOT

I so čovekOT

$\mathrm{L} n a, v o, d o, o d . . c ̌ o v e k O T$

$\mathrm{G}$ na čovekOT ${ }^{4}$

The central "pronominal" innovation of the SES was the development of the article, the triple article, whose main function is to (contextually, pragmatically) identify the third persons, inanimate material objects included. ${ }^{5}$ The triple article enables the inclusion of the spatial parameter into the identification process, with the $o v$-forms for what is near the speaker, on-forms for what is distant, and $t$-forms for what is neutral in so far as space is concerned. Mutatis mutandis - through semantic derivation - with the same means the "emotional space", the empathy, simpathy, antipathy can be expressed.

Also the spatial pronominal adverbs as Mac. tuka/ ovde, onde, tamu... function as "spatial shifters" and help to precise the contextual / consituational location of an event.

\section{Gender hierarchy}

There is no clear correlation in Proto-Slavic between the biological gender and grammatical gender, nor between the grammatical gender and the morphological structure of the lexeme. Consequently, there are no regular markers for the distinctions of biological gender.

The semantic category of gender is founded on two oppositions, one privative: / +/- animate/, and one equipollent: /+ masculine/ vs /+ feminine /. Thus our problem in this section is: are there in SES some marginal signals showing the hierarchy of the three gender classes: (a) 'animate' vs 'inanimate', and then (b) 'masculine' vs 'feminine', and if so, are they inherited, introduced in

4 There is also another solution, more extended in Bulgarian than in Macedonian: postposition of the dative clitic, as in majka mi, sestra ti, etc.; finaly with /+human/ nouns there is still other solution, cf. kniga na Petre $\sim$ Petrova kniga, griža na majka $\sim$ majčina griža, etc.

${ }^{5}$ In Proto-Slavic there was an attempt to introduce postpositive anaphoric article glued to adjective modifiers, but it evolved into a syntactic, distributional phenomenon without semantic relevance. 
the "Balkanization era" and under the Balkan influence, or are they of a still newer origin?

Ad a. The neutral, unmarked character of the (nomen omen!) neuter gender can be seen in its use in typically depersonalized constructions, i.e. constructions where the performer/ agent is unknown and/or not pointed out / not named, as e.g. Mac. Se slučilo nešto lošo 'Something bad happened', Togaš kažuvalo deka 'It was interpreted that', etc. These are old, inherited constructions.

Ad b. In the domain of word formation we find some structures showing the "masculine domination", e.g. Mac. Dojdoa Vlastovci. 'Vlasto and family', Marjanovci letuvaat na more 'Marjan and his family', where only the husband's name (never the wife's name) can appear; cf. also professional names such as profesor $\sim$ profesorka, minister $\sim$ ministerka, prodavač $\sim$ prodavačka, and the like, where the feminative suffix is glued to the name of the masculine performer. There are also numerous pejorative names for women, but very few, if ever, for men, and so on. It should be also mentioned that a group of both sexes is always referred to with the masculine plural form. However, to our thinking, these are the echoes of the local social and cultural stratigraphy, not connected with the situation in other Balkan languages.

Perhaps it is not incidental that in the system of pronominal identifying replicas we find $\mathbf{N}=\mathbf{M}$, and not $\mathbf{N}=\mathbf{F}$ syncretism.

\section{Individual vs multitude}

In Proto-Slavic there were three series of grammaticalized constructions informing on the number of denotates of the concept referred to in a NP: 'one' (singular construction), 'two' (dual construction) and 'more than two' (plural construction). In the course of time in the majority of Slavic languages the dual was lost.

In Macedonian dialects two new types of serial constructions were born and they were introduced into the standard norm: a) collective plural, and b) counted plural. They were both local innovations in the domain of word formation, collective plural derived from masculine and feminine nouns with the old suffix *-bje, meaning 'great quantity (of a substance) and/or great number of denotates of some concept taken as a whole, cf. Mac. vog'e 'much water, as in a water- fall', livag'e 'great areal covered with meadows', lisje 'great 
number of leafs', etc., and counted plural appearing in sintagmes with numbers and derived from masculine nouns with the old dual ending *-a, cf.Mac. pet moliva 'five pencils', tri voza 'three trains', etc. Both these constructions are local innovations not connected with the processes of Balkanization.

\section{Conclusion}

As mentioned in the foreword to this text, the majority of impulses stimulating the evolution of language come from the semantic plane. Such is also the character of impulses stimulating the so-called processes of Balkanization. Thus, the evolution of the SouthEasternSlavic as a member of the Balkan Linguistic League illustrates the accelerated evolution in a multilingual environment. The results are strikingly similar to those known from the history of the Romance languages and also from the history of English in the WestEuropean MiddleAges and they led - in both cases - to what we call to-day the Standard Average European. H.I. Aronson (2007: 31) writes: "By not restricting our investigations to the narrow bounds of the Balkan Sprachbund, we can place the Balkan languages into larger contexts. One of these larger contexts is the general European one. Viewing the Balkan languages in this context, one is struck by the strong typological resemblances between these languages and many of the languages of Western and Central Europe". Let us repeat once more: we are concerned here with the universal direction of language evolution and one of the first bearers of the results of the accelerated speed of this evolution "on the map of Europe" is just SouthEastern Slavic. Quod erat demonstrandum.

\section{Bibliography}

(Verbal System)

Видоески Б., 1998, Дијалектите на македонскиот јазик, Том 1, МАНУ, Скопје: Македонска Академија на науките и уметностите.

Видовски Б., 1999, Дијалектите на македонскиот јазик, Том 2, МАНУ, Скопје: Македонска Академија на науките и уметностите.

Видовски Б., 1999, Дијалектите на македонскиот јазик, Том 3, МАНУ, Скопје: Македонска Академија на науките и уметностите 
Голомь 3., 1970, За “механизмот” на словенско-романските односи на Балканскиот полуостров, Македонски јазик, год. XXI, Скопје: ?.

Голомь 3., 1974, Значењето на македонскиот јазик за балканистичките cmудuи, Пристапни предавања на новите членови на МАНУ, Скопје?.

ДЕмирал Ш.,1994, Балканска лингвистика, Скопје.

Илиевски Хр. П., 1988, Балканолошки лингвистички студии, Скопје: ИМЈ.

Конески Б., 1981, Граматика на македонскиот јазик, Скопје: Култура.

Конески Б., 1982, Историја на македонскиот јазик, Скопје: Култура.

Певв К., 1987/1988, Кукушкиот говор, т. 1-2, Скопје: НИО Студентски збор.

Тополињска 3., 1992, За прагматичната и семантичната мотивација на морфосинтаксички балканизми, Прилози XVI, Скопје: МАНУ.

ТополињскА 3., 1997, 'Семантичка категорија (не)фактивност во словенските јазици’ Прилози. Одделение за лингвистика и литературна наука, XXII, 1-2, Скопје: МАНУ, р. 93-103.

Фридман В., 2011, Македонистички студии, Скопје: МАНУ.

Фридман В., 2001, Граматикализацијата на балканизмите во македонскиот јазик Македонски јазик, бр. 51-52, p. 31-38.

Cienki A., 1989, Spatial cognition and the semantics of prepositions in English, Polish, and Russian, München: Verlag Otto Sagner.

Friedman A.V., 1977, The Gramatical Categories of the Macedonian Indicative, Columbus, Ohio: Slavica Publishers.

Friedman A.V., 1983, Gramatical Categories and a Comparative Balcan Grammar, Band 8, Berlin: Ziele und Wege der Balkanlinguistik.

Markoviкu M., 2012, Macedonian language from the perspective of its Balkan Environment (Language Tendencies), „Colloquia Humanistica”, vol. 1: The Continuity and Discontinuity as a Research Problem in the Macedonian, Balkan and European Cultural Context, Warszawa.

Nevaci M., 2006, Verbul în aromanâ - structurâ şi valori, Bucureşti: Editura Academiei Române.

Sкок P., 1971, Etimologijski rječnik hrvatskoga ili srpskoga jezika, Zagreb: Jugoslavenska Akademija Znanosti i Umjetnosti.

SŁAwSKi F., 1974. Słownik prasłowiański, t. 1, Wrocław: Ossolineum.

Solecka K. M., 1983, Semantyka czasowników ruchu w języku macedońskim, Katowice: Uniwersytet Śląski.

Topolińska Z., 2010, The Balkan Sprachbund from a Slavic perspective, Зборник Матице српске за филологију и лингвистику 53/1, p. 33-60.

TopolińsKa Z., 2011, Dlaczego na?, Јужнословенски филолог LXVII, p. 101-108. 
(Nominal system)

Aronson H.I., 2007, The Balkan Linguistic League, "Orientalism" and Linguistic Typology, The Kenneth E. Naylor Memorial Lecture series, number 4, Ann Arbor - New York: Beech Stave Press.

Asenova P., 1989, Balkansko ezikoznanie. Osnovni problemi na balkanski/ ezikov $s x w z$, Sofi: Izdatelstvo "Nauka i izkustvo".

Fillmore Ch.J., 1966, Toward a modern theory of case, The Ohio State University project on linguistic analysis, Report No 13, Columbus: Ohio State University.

Fillmore Ch.J., 1968, The Case for Case, in: Ch.J. Fillmore, Form and Meaning in Language, p. 21-294.

GoŁą Z., 1989 The language of the first Slavs in Greece: VII-VIII centuries, Prilozi na MANU, OLLN XIV/2, s. 5-46.

Ostrogorski G., 1998, Istorija Vizantije, Alfa: Narodna Kniga.

Schenker A.M., 1996, The Dawn of Slavic, New Haven and London: Yale University Press.

Schenker A.M., Stankiewicz E. (eds.), 1980, The Slavic Literary Languages, New Haven, CT: Yale Concilium on International and Area Studies.

SŁawski F., 1954, Gramatyka języka butgarskiego, Warszawa: Państwowe Wydawnictwo Naukowe.

TopolińsKa Z., 1996, Anthropocentric Language Theory as Organizing Principle of the Slavic Case System, Biuletyn Polskiego Towarzystwa Językoznawczego LII, s. $57-72$.

Topolińska Z., 2010, W sprawie przypadka. Gawęda językoznawcza, Poznań: Wydawnictwo Naukowe UAM.

TopoLiŃska Z., 2014, Relacja: predykat > argument - centralne ogniwo struktury tekstu, Rocznik Slawistyczny LXIII, s. 145-155.

\section{Wgląd w historię slowiańskich języków Bałkanów. Perspektywa macedońska}

(streszczenie)

Celem artykułu jest wskazanie głównych procesów, które sprawiły, że językowy rozwój południowo-wschodniej Słowiańszczyzny (tj. dialektów języków macedońskiego, bułgarskiego i części dialektów południowej Serbii) poszedł odmienną drogą niż rozwój pozostałych, bardziej konserwatywnych, słowiańskich kompleksów dialektalnych. W wypadku południowo-wschodniej Słowiańszczyzny jest to rozwój motywowany w znacznej mierze przez tzw. zmiany kontaktowe, tj. przez 
interferencję języków o różnej strukturze typologicznej, w wielojęzycznych strukturach administracyjno-państwowych, które narzucają potrzebę komunikacji podmiotów nie władających dobrze językiem rozmówcy. W efekcie jest to rozwój, który odkrywa właściwą hierarchię komunikatywną przekazywanych informacji i prowadzi do regularyzacji (gramatykalizacji) eksponentów informacji najważniejszej dla szczęśliwego przebiegu aktu komunikacji. W systemie werbalnym jest to przede wszystkim informacja z pola semantycznego oceny prawdziwościowej faktów, o których mowa, w systemie nominalnym - informacja umożliwiająca prawidłową identyfikację zdarzeń, o których mowa, i protagonistów tych zdarzeń. Przedstawiamy tę problematykę z perspektywy mechanizmów ewolucji charakterystycznych dla macedońskiego terytorium językowego, pokazując, jak wspomniane impulsy semantyczne przekształcają gramatyczne (morfologiczne i syntaktyczne) dziedzictwo prasłowiańskie. W tym związku przyciąga naszą uwagę analogia między kierunkiem i rezultatami ewolucji tzw. bałkańskiej ligi językowej i procesami, które w późnym średniowieczu przyniosły uderzająco podobne rezultaty w rozwoju romańskich języków zachodnio-europejskich i języka angielskiego. 
